\title{
Inhaled Nitric Oxide versus Inhaled Prostacyclin and Intravenous versus Inhaled Prostacyclin in Acute Respiratory Failure with Pulmonary Hypertension in Piglets
}

\author{
GERFRIED ZOBEL, DRAGO DACAR, SIEGFRIED RÖDL, AND INGEBORG FRIEHS \\ Departments of Pediatrics [G.Z., S.R.] and Cardiac Surgery [D.D., I.F.], University of Graz, Austria
}

\begin{abstract}
This study was a prospective, randomized design to compare oxygenation and pulmonary hemodynamics between inhaled nitric oxide (NO) and inhaled prostacylcin $\left(\mathrm{PGI}_{2}\right)$, and between inhaled and i.v. $\mathrm{PGI}_{2}$ in acute respiratory failure with pulmonary hypertension. Acute respiratory failure with pulmonary hypertension was induced in 12 piglets weighing $9-12 \mathrm{~kg}$ by repeated lung lavages and a continuous infusion of the stable endoperoxane analogue of thromboxane. Thereafter the animals were randomly assigned either for $\mathrm{NO}$ or $\mathrm{PGI}_{2}$ application. All animals were treated with different concentrations of $\mathrm{NO}$ or different doses of $\mathrm{PGI}_{2}$ applied i.v. and inhaled in random order. Continuous monitoring included ECG, central venous pressure (CVP), mean pulmonary artery pressure (MPAP), mean arterial pressure (MAP), artertial oxygen saturation $\left(\mathrm{SaO}_{2}\right)$, and mixed venous oxygen saturation $\left(\mathrm{SvO}_{2}\right)$ measurements. NO inhalation of 10 ppm resulted in a significant increase in $\mathrm{PaO}_{2} /$ fraction of inspired oxygen $\left(\mathrm{FiO}_{2}\right)$ from $7.8 \pm 1.34 \mathrm{kPa}$ to $46.1 \pm 9.7 \mathrm{kPa}$. MPAP decreased significantly from $5.1 \pm 0.26 \mathrm{kPa}$ to $3.7 \pm 0.26 \mathrm{kPa}$ during inhaled $\mathrm{NO}$ of $40 \mathrm{ppm}$; i.v. infusion of $\mathrm{PGI}_{2}$ slightly increased oxygenation parameters. A significant increase in $\mathrm{PaO}_{2}$ $\mathrm{FiO}_{2}$ up to $32.4 \pm 3.1 \mathrm{kPa}$ was observed during $\mathrm{PGI}_{2}$ aerosol delivery $(p<0.01)$; i.v. $\mathrm{PGI}_{2}$ decreased MAP from $11.5 \pm 0.39$ $\mathrm{kPa}$ to $9.8 \pm 0.66 \mathrm{kPa}(p<0.05)$ and MPAP from $5.8 \pm 0.53$ $\mathrm{kPa}$ to $4.5 \pm 0.66 \mathrm{kPa}$, respectively $(p<0.05)$. $\mathrm{PGI}_{2}$ aerosol delivery significantly decreased the MPAP to $3.7 \pm 0.53 \mathrm{kPa}(p$ $<0.05)$ without influencing the MAP. It was concluded that inhaled $\mathrm{NO}$ and inhaled $\mathrm{PGI}_{2}$ act as selective pulmonary vasodilators in acute respiratory failure with pulmonary hypertension
\end{abstract}

ABSTRACT

In 1987 NO was reported to be an important endotheliumderived relaxing factor $(1,2)$. NO is synthesized in the vascular endothelial cell from L-arginine by NO synthase. It rapidly diffuses into the vascular smooth muscle cell and acts by stimulation of guanylate cyclase producing cGMP which me-

Reccived August 23, 1994; accepted February 20, 1995.

Correspondence and reprint requests: Gerfried Zobel, M.D., Department of Pediatrics, University of Graz, Auenbruggerplatz, A-8036 Graz, Austria.

Supported in part by grants of the Gesellschaft zur Förderung der Gesundheit des Kindes. resulting in improved oxygenation mainly due to improved mismatch of pulmonary perfusion and ventilation. Intravenous $\mathrm{PGI}_{2}$ improves oxygenation and pulmonary hemodynamics to a lesser extent than aerosolized $\mathrm{PGI}_{2}$ and has the risk of systemic hypotension at a higher dose. (Pediatr Res 38: 198-204, 1995)

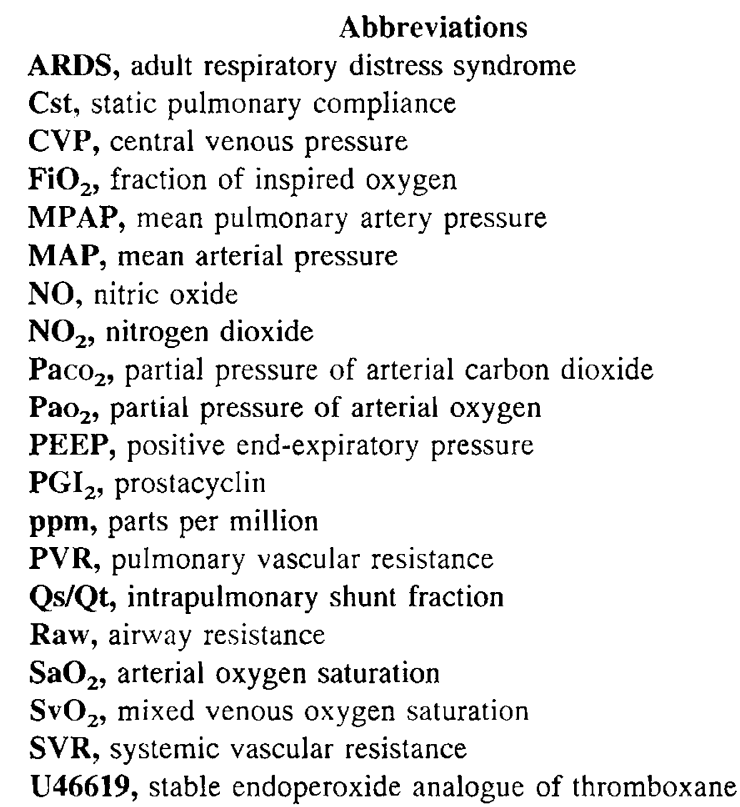

diates vasodilation (3). In the vascular system NO is rapidly bound to $\mathrm{Hb}$ forming nitrosylhemoglobin and methemoglobin (4). Therefore, NO acts locally and produces no effects on the systemic vasculature. NO is an unstable free radical, and in the presence of high oxygen concentrations is oxidized to $\mathrm{NO}_{2}$ which might cause lung injury $(5,6)$.

Recently, inhaled NO has been described as an effective selective pulmonary vasodilator in different experimental models of pulmonary hypertension (7-11). It improved oxygenation and reduced elevated pulmonary artery pressure in neo- 
nates, infants, and adults with pulmonary hypertension or acute respiratory failure combined with pulmonary hypertension (12-19). Inhaled NO improves ventilation/perfusion mismatch by selectively vasodilating pulmonary vessels of ventilated areas.

$\mathrm{PGI}_{2}$, an arachidonic acid metabolite, is a potent dilator of the arterial and venous vessels by increasing the concentration of cAMP in vascular smooth muscle cells (20). $\mathrm{PGI}_{2}$ has been applied in a variety of clinical and experimental conditions with pulmonary hypertension (21-25). However, vasodilation occurs in both the pulmonary and systemic vessels which might result in systemic hypotension. In addition, as $\mathrm{PGI}_{2}$ vasodilates pulmonary vessels in ventilated and nonventilated areas of the lung, increased intrapulmonary shunt with increased venous admixture might occur. Recently, aerosolized $\mathrm{PGI}_{2}$ has been reported both in clinical and experimental settings to be a selective pulmonary vasodilator without side effects on the systemic vasculature $(26,27)$.

The aim of this study is to compare the pulmonary and hemodynamic effects of inhaled $\mathrm{NO}$ and inhaled $\mathrm{PGI}_{2}$ in an animal model of acute respiratory failure with pulmonary hypertension. In addition, we evaluated the differences between inhaled and i.v. $\mathrm{PGI}_{2}$ on the pulmonary and hemodynamic effects.

\section{METHODS}

The protocol was approved by the Institutional Animal Research Committee and the care of the animals was in accordance with guidelines for ethical animal research.

In 12 piglets of either sex, weighing $10 \pm 0.6 \mathrm{~kg}$, premedicated with azaperone $(8 \mathrm{mg} / \mathrm{kg})$ and atropine $(0.02 \mathrm{mg} / \mathrm{kg})$, anesthesia was induced with ketamine $(10 \mathrm{mg} / \mathrm{kg})$ and thereafter maintained by a continuous infusion of fentanyl $(0.15$ $\mu \mathrm{g} / \mathrm{kg} / \mathrm{min}$ ), pentobarbital sodium (4 $\mathrm{mg} / \mathrm{kg} / \mathrm{h}$ ), and pancuronium $(0.3 \mathrm{mg} / \mathrm{kg} / \mathrm{h})$. After placing a $5.5-\mathrm{mm}$ inside diameter Hi-Lo cuffed tube (Hi-Lo jet tube, National Catheter Corp., Malinckrodt, Glen Falls, NY) via tracheostomy, controlled mechanical ventilation was established using a volume controlled, time cycled ventilator (Veolar, Hamilton Comp., Rhazüns, Switzerland). Tidal volume was set at $10-12 \mathrm{~mL} / \mathrm{kg}$, respiratory rate at $20 / \mathrm{min}$, inspiratory/expiratory ratio at $1: 2$, PEEP at $4 \mathrm{cmH}_{2} \mathrm{O}$, and $\mathrm{FiO}_{2}$ at 0.21 . Initially a 4 Fr doublelumen catheter (Duocath, Peter von Berg Medizintechnik, Kirchseeon, FRG) was inserted into the right subclavian vein for nutrition and anesthesia. After induction of anesthesia, a Ringer solution was infused, initially, at a rate of $10 \mathrm{~mL} / \mathrm{kg}$ in $30 \mathrm{~min}$ followed by a continuous infusion of $5 \mathrm{~mL} / \mathrm{kg} / \mathrm{h}$. A 5.5 Fr thermodilution $\mathrm{O}_{2}$ saturation fiber-optic pulmonary artery catheter (Edwards Swan-Ganz Oximetry TD catheter, Edwards Critical Care Division, Irvine, CA) was placed into the pulmonary artery by peripheral cutdown of the external jugular vein. A 4 Fr $\mathrm{O}_{2}$ saturation catheter (Edslab double lumen $\mathrm{O}_{2}$ Sat II catheter, Edwards Critical Care Division) was inserted via the right common carotid artery and placed into the thoracic aorta for continuous arterial oximetry measurement. A short 16gauge catheter (Abbocath, Abbott Ireland LTD, Sligo, Republic of Ireland) was placed into the femoral artery for continuous pressure recording. A second 4 Fr double-lumen catheter (Duocath, Peter von Berg Medizintechnik) was placed via the left external jugular vein.

Hemodynamic monitoring. Heart rate and rhythm, right atrial, pulmonary artery, and peripheral artery pressures were recorded continuously on a multichannel recorder (SMU 612 monitor, PPG Hellige Corp., Freiburg, FRG) using 0.9\% saline filled transducers (Monitoring Kit NM-081-D, Peter von Berg Medizintechnik). All pressures were referenced to the midthorax. Cardiac output was measured at end-expiration by the thermodilution technique as the mean of three determinations after injection of $5 \mathrm{~mL} 0^{\circ} \mathrm{C} 0.9 \%$ saline. SVR was calculated as MAP divided by cardiac output. PVR was calculated as MPAP divided by cardiac output. Two oxygen saturation monitors (Baxter Sat2 Oximeter; Baxter Healthcare Corporation, Edwards Critical Care Division, Irvine, CA) were used for continuous arterial and mixed venous oximetry measurements.

Respiratory monitoring. Arterial and mixed venous blood samples were taken for measurements of $\mathrm{Hb}$, oxygen saturation, $\mathrm{PO}_{2}, \mathrm{PCO}_{2}$, and $\mathrm{pH}$ using an automatic blood gas system (AVL 995, AVL Corp., Graz, Austria). In addition the $\mathrm{SaO}_{2}$ and $\mathrm{SvO}_{2}$ oxygen saturations and arterial methemoglobin fraction (CO-Oxylite AVL 912, AVL Corp.) were analyzed. Endtidal $\mathrm{CO}_{2}$ concentrations and the fraction of inspired and expired oxygen were measured with a multigas analyzer (PPG Hellige Corp., Freiburg, FRG). Airway pressures, tidal volume, Cst, and Raw were measured with a Bicore CP-100 monitor (Bicore Monitoring Systems, Irvine, CA).

Administration of $\mathbf{P G I}_{2}$. $\mathrm{PGI}_{2}$ was supplied as the sodium salt of epoprostenol (Flolan, Wellcome, London, UK) dissolved in glycine buffer and diluted with $0.9 \%$ saline at a concentration of $10 \mu \mathrm{g} / \mathrm{ml}$. It was applied as an aerosol or as continuous infusion at the same concentration. For inhalation of $\mathrm{PGI}_{2}$ as aerosol a nebulizer chamber (Intersurgical Ltd., Twickenham, UK) and an oxygen flowmeter (Dräger Austria GesmbH., Vienna, Austria) with flow rates of $3-6 \mathrm{~L} / \mathrm{min}$ was used. The aerosol was delivered at the connection of the ventilatory circuit with the flow sensor of the ventilatory circuit (MR 39015 mm tubings, Fisher \& Paykel Healthcare, Panmure, Auckland, NZ) near the endotracheal tube. Primarily, the nebulizer chamber was filled with $1 \mathrm{~mL}$ of the above described $\mathrm{PGI}_{2}$ solution followed by a continuous infusion of $30-60$ $\mathrm{ng} / \mathrm{kg} / \mathrm{min}$ into the nebulizer chamber via a 20 -gauge catheter (Venflon, Viggo-Spectramed, Helsinborg, Sweden) inserted into a small bored side hole of the nebulizer chamber. During aerosol delivery of $\mathrm{PGI}_{2}$ the tidal volume of the ventilator was reduced to obtain comparable mean airway pressures. Intravenous infusion of $\mathrm{PGI}_{2}$ was started at $5 \mathrm{ng} / \mathrm{kg} / \mathrm{min}$ and was subsequently increased up to $40 \mathrm{ng} / \mathrm{kg} / \mathrm{min}$.

Administration of NO. NO was obtained as $900 \mathrm{ppm}$ in nitrogen (Pulmomix forte, Messer-Griesheim, Austria) and applied using the Pulmonox system. The Pulmonox is a microprocessor controlled system which allows NO delivery at concentrations from 1 to $40 \mathrm{ppm}$ and continuous inspiratory measurement of $\mathrm{NO} / \mathrm{NO}_{2}$ using the chemiluminescence method. A flow-box incorporated into the inspiratory limb of the ventilatory circuit transfers the inspiratory flow rate of the ventilator to the Pulmonox system which adapts the NO dosage 
on a continuous basis. NO was administered into the inspiratory limb of the ventilatory circuit close to the endotracheal tube using an airway sampling adapter (Engström Sampling adapter, Gambro Engström, Bromma, Sweden). The system was calibrated before each treatment/measurement with special calibration gases.

Protocol. After this instrumentation the animals were allowed to rest for $30 \mathrm{~min}$ before control measurements were performed. Before starting the lung lavage procedure the $\mathrm{FiO}_{2}$ of the ventilator was increased to 1.0 and the PEEP levels to 1 $\mathrm{kPa}$. In addition, a Tris infusion was started to obtain a stable $\mathrm{pH}$ throughout the study period. Acute respiratory failure $\left(\mathrm{SaO}_{2}<85 \%\right)$ was induced by repeated lung lavages using $0.9 \%$ saline $(20-30 \mathrm{~mL} / \mathrm{kg} /$ lavage $)$. After the last lung lavage the stable endoperoxide analog of thromboxane (U46619, Cascade Biochem Ltd., Bershire, UK) was infused at a rate of $0.4-0.8 \mu \mathrm{g} / \mathrm{kg} / \mathrm{min}$ to increase the mean PAP above $4.6 \mathrm{kPa}$. Thereafter the animals were randomly assigned either for NO or $\mathrm{PGI}_{2}$ application. To obtain a pulmonary vasodilator doseresponse curve during U46619 infusion all animals were treated with different concentrations of $\mathrm{NO}(1,2,5,10,20$, and $40 \mathrm{ppm})$ or different doses of $\mathrm{PGI}_{2}(5,10,20$, and $40 \mathrm{ng} / \mathrm{kg} / \mathrm{min}$ as continuous i.v. infusion and 30 and $60 \mathrm{ng} / \mathrm{kg} / \mathrm{min}$ as an aerosol). Intravenous and inhaled $\mathrm{PGI}_{2}$ were applied in random order. Measurements were taken after 10-15 min of each NO concentration or $\mathrm{PGI}_{2}$ dosis or after a stable period of $5 \mathrm{~min}$. Five minutes after termination of $\mathrm{NO}$ or $\mathrm{PGI}_{2}$ application a last measurement was taken under hypoxic conditions.

All animals tolerated the experimental protocol. After the end of the trial the animals were killed with an overdose of potassium chloride.

Data analysis. Values are given as mean \pm SEM. Initially a multifactorial analysis of variance for repeated measures was applied using the Statview 4.0 software for Macintosh. If a significant difference was determined, the intragroup differences were determined using the paired $t$ test and the intergroup differences by unpaired $t$ test with a $p$ value of $<0.05$ being considered significant.

\section{RESULTS}

Three to six lung lavages significantly decreased Cst from $1.7 \pm 0.04$ to $0.84 \pm 0.02 \mathrm{~mL} / \mathrm{kPa} / \mathrm{kg}(p<0.01)$ and $\mathrm{Pao}_{2} /$ $\mathrm{FiO}_{2}$ from $65.2 \pm 1.5$ to $8.2 \pm 0.5 \mathrm{kPa}(p<0.01)$. Simultaneously Raw increased from $4.6 \pm 0.13$ to $7.4 \pm 0.3 \mathrm{kPa} / \mathrm{L} / \mathrm{s}$
( $p<0.01$ ). The infusion of U46619 significantly increased MPAP and PVR by 141 and $321 \%$, respectively $(p<0.01)$.

NO. Blood gas parameters, arterial and mixed venous oxygen saturations, mean airway pressure, and intrapulmonary shunt fraction are summarized in Table 1. NO inhalation resulted in a significant increase in oxygenation parameters. The highest $\mathrm{PaO}_{2} / \mathrm{FiO}_{2}$ values of $46.1 \pm 9.7 \mathrm{kPa}$ were observed during inhalation of $10 \mathrm{ppm}$ NO. A further increase in the NO concentration resulted in a slight decrease in $\mathrm{PaO}_{2} / \mathrm{FiO}$ values. When NO concentration was stepwise increased from 1 to 40 ppm, $\mathrm{FiO}_{2}$ decreased from 1.0 to $0.9 \pm 0.05$ ( $\left.p<0.01\right)$. Qs/Qt improved significantly during NO inhalation of $10-40 \mathrm{ppm}$. No significant differences were observed in pulmonary mechanics during NO inhalation.

The hemodynamic parameters during NO inhalation are summarized in Table 2. There was no change in heart rate, CVP, MAP, and PVR during inhaling different doses of NO. MPAP decreased significantly from $5.1 \pm 0.02 \mathrm{kPa}$ to $3.7 \pm$ $0.02 \mathrm{kPa}(p<0.05)$ during inhalation of $40 \mathrm{ppm} \mathrm{NO}$. Although cardiac output decreased slightly by $19 \%$, SVR increased significantly by $35 \%(p<0.05)$ during NO inhalation with simultaneous infusion of U46619. Methemoglobin levels were $1.2 \pm 0.1 \%$ during inhalation of $1 \mathrm{ppm}$ of $\mathrm{NO}$ and increased to $2.1 \pm 0.25 \%(p<0.01)$ when NO concentration was increased to $40 \mathrm{ppm}$. $\mathrm{NO}_{2}$ levels were below $0.5 \mathrm{ppm}$ during inhalation of 1 to $40 \mathrm{ppm}$ NO.

$\boldsymbol{P G I}_{2}$. Blood gas parameters, arterial and mixed venous oxygen saturations, mean airway pressure, and intrapulmonary shunt fraction are given in Table 3. Intravenous infusion of $\mathrm{PGI}_{2}$ slightly increased oxygenation parameters. The highest $\mathrm{PaO}_{2} / \mathrm{FiO}_{2}$ values of $14.1 \pm 4.1 \mathrm{kPa}$ were observed during infusion of $40 \mathrm{ng} / \mathrm{kg} / \mathrm{min}$ of $\mathrm{PGI}_{2}$. A significant increase in $\mathrm{PaO}_{2} / \mathrm{FiO}_{2}$ up to $32.4 \pm 3.1 \mathrm{kPa}$ was observed during $\mathrm{PGI}_{2}$ inhalation $(p<0.01)$. During inhaled $\mathrm{PGI}_{2}$ the $\mathrm{Qs} / \mathrm{Q}$ t values were significantly lower than during i.v. $\mathrm{PGI}_{2}$ application $(p<$ 0.05). Pulmonary mechanics (Cst, Raw) did not change significantly during inhaled and i.v. $\mathrm{PGI}_{2}$ application. During i.v. $\mathrm{PGI}_{2}$ application, MAP and MPAP decreased by 15 and $23 \%$, respectively $(p<0.05)$, and heart rate increased by $18 \%(p<$ $0.05)$. There was no change in PVR and SVR. $\mathrm{PGI}_{2}$ aerosol application did not change heart rate, MAP, and CVP. However, a significant decrease in MPAP and PVR by 22 and $36 \%$, respectively $(p<0.05)$ was observed.

Table 1. Blood gases, oxygenation variables, mean airway pressure and intrapulmonary shunt fraction in six piglets with acute respiratory failure and pulmonary hypertension pre, during, and post NO inhalation (mean \pm SEM)

\begin{tabular}{lccccccc}
\hline \multicolumn{1}{c}{ Parameters } & Baseline & Lavage + U46619 & NO-1ppm & NO-5ppm & NO-10ppm & NO-40ppm \\
\hline $\mathrm{pH}$ & $7.35 \pm 0.01$ & $7.37 \pm 0.02$ & $7.39 \pm 0.02$ & $7.42 \pm 0.01$ & $7.42 \pm 0.02$ & $7.41 \pm 0.02$ & $7.37 \pm 0.02 \dagger$ \\
$\mathrm{PaO}_{2} / \mathrm{FiO}_{2}(\mathrm{kPa})$ & $63 \pm 0.8$ & $7.8 \pm 1.3^{* *}$ & $14.3 \pm 0.1^{* * \dagger}$ & $36.1 \pm 6.9^{* * \dagger}$ & $46.1 \pm 9.7 \dagger$ & $43.4 \pm 9.4$ & $10.1 \pm 1.8^{* *} \dagger$ \\
$\mathrm{SaO}_{2}(\%)$ & $97 \pm 0.9$ & $79 \pm 4.1^{* *}$ & $90 \pm 5.1^{* \dagger}$ & $99 \pm 0.4 \dagger$ & $99 \pm 0.4$ & $99 \pm 0.3$ & $82 \pm 3.3^{* * \dagger}$ \\
$\mathrm{SvO}_{2}(\%)$ & $71 \pm 1.8$ & $45 \pm 3.7^{* *}$ & $60 \pm 3.7^{* * \dagger}$ & $66 \pm 5.1$ & $66 \pm 4.7$ & $65 \pm 5.2$ & $40 \pm 5.4^{* *} \dagger$ \\
$\mathrm{Paw}(\mathrm{kPa})$ & $0.91 \pm 0.06$ & $1.58 \pm 0.03^{* *}$ & $1.56 \pm 0.04^{* *}$ & $1.63 \pm 0.03^{* *}$ & $1.61 \pm 0.03^{* *}$ & $1.63 \pm 0.04^{* *}$ & $1.66 \pm 0.04^{* *}$ \\
$\mathrm{Qs} / \mathrm{Qt}(\%)$ & $16 \pm 1.2$ & $53 \pm 6.2^{* *}$ & $43 \pm 5.1^{* * \dagger}$ & $22 \pm 3.3 \dagger$ & $17 \pm 3.2$ & $17 \pm 3.4$ \\
\hline
\end{tabular}

$* p<0.05$

${ }^{* *} p<0.01$ denotes significant differences to the baseline levels.

$\dagger p<0.05$ denotes a significant difference to the former measured value. 
Table 2. Hemodynamic data in six piglets with acute respiratory failure and pulmonary hypertension pre, during and post NO inhalation (mean \pm SEM)

\begin{tabular}{|c|c|c|c|c|c|c|c|}
\hline Parameters & Baseline & Lavage + U46619 & NO-1ppm & NO-5ppm & NO-10ppm & NO-40ppm & Post-NO \\
\hline Heart rate/min & $135 \pm 11$ & $137 \pm 9$ & $127 \pm 6$ & $127 \pm 3$ & $123 \pm 3$ & $122 \pm 10$ & $164 \pm 17$ \\
\hline Cardiac output (L/min) & $2.8 \pm 0.3$ & $1.6 \pm 0.1^{* *}$ & $1.6 \pm 0.2 * *$ & $1.5 \pm 0.2 * *$ & $1.4 \pm 0.2 * *$ & $1.3 \pm 0.1^{* *}$ & $1.1 \pm 0.1^{* *}$ \\
\hline MAP (kPa) & $9.1 \pm 0.5$ & $13.3 \pm 0.6^{* *}$ & $13.3 \pm 0.4 * *$ & $13.6 \pm 0.5^{* *}$ & $13.9 \pm 0.5^{*}$ & $13.9 \pm 70.9^{* *}$ & $12.3 \pm 1.4^{* * \dagger}$ \\
\hline PAP $(\mathrm{kPa})$ & $1.9 \pm 0.2$ & $5.1 \pm 0.2 * *$ & $4.3 \pm 0.2^{* * \dagger}$ & $3.9 \pm 0.4^{* *}$ & $3.9 \pm 0.4^{* *}$ & $3.7 \pm 0.3^{* *}$ & $6.3 \pm 4 * * \dagger$ \\
\hline $\operatorname{PVR}(\mathrm{kPa} / \mathrm{L} / \mathrm{min})$ & $0.73 \pm 0.70 .1$ & $3.2 \pm 0.47^{* *}$ & $3.1 \pm 0.7^{* *}$ & $3.2 \pm 0.7^{* *}$ & $3.3 \pm 0.78 * *$ & $3.2 \pm 0.67^{* *}$ & $5.7 \pm 0.78 * * \dagger$ \\
\hline $\operatorname{SVR}(\mathrm{kPa} / \mathrm{L} / \mathrm{min})$ & $3.4 \pm 0.43$ & $8.2 \pm 0.62 * *$ & $9.0 \pm 1.0 * *$ & $9.5 \pm 1.1 * *$ & $10.9 \pm 1.2 * * \dagger$ & $11.1 \pm 0.77^{* *}$ & $10.9 \pm 1.26 * *$ \\
\hline PVR/SVR & $0.22 \pm 0.02$ & $0.39 \pm 0.04 * *$ & $0.32 \pm 0.03^{* * \dagger}$ & $0.29 \pm 0.03^{*}$ & $0.26 \pm 0.03 *$ & $0.28 \pm 0.04 *$ & $0.53 \pm 0.06 * * \dagger$ \\
\hline
\end{tabular}

$* p<0.05$.

$* * p<0.01$ denotes significant differences to the baseline levels.

$\dagger p<0.05$ denotes a significant difference to the former measured value.

Table 3. Blood gases, oxygenation variables, mean airway pressure, and intrapulmonary shunt fraction in six piglets with acute respiratory failure and pulmonary hypertension pre, during, and post $P G I_{2}$ application (mean $\pm S E M$ )

\begin{tabular}{|c|c|c|c|c|c|c|c|}
\hline Parameters & Baseline & Lavage + U46619 & $\begin{array}{c}\mathrm{PGE}_{2}-5 \\
\text { (ng/kg/min) }\end{array}$ & $\begin{array}{c}\mathrm{PGI}_{2}-10 \\
(\mathrm{ng} / \mathrm{kg} / \mathrm{min})\end{array}$ & $\begin{array}{c}\mathrm{PGI}_{2}-40 \\
\text { (ng/kg/min) }\end{array}$ & $\begin{array}{c}\mathrm{PGI}_{2} \text {-Aerosol } \\
(\mathrm{ng} / \mathrm{kg} / \mathrm{min})\end{array}$ & Post-PGI ${ }_{2}$ \\
\hline $\mathrm{pH}$ & $7.39 \pm 0.02$ & $7.35 \pm 0.03$ & $7.36 \pm 0.03$ & $7.37 \pm 0.03$ & $7.37 \pm 0.02$ & $7.42 \pm 0.02 \dagger$ & $7.36 \pm 0.02 \uparrow$ \\
\hline $\mathrm{PaO}_{2} / \mathrm{FiO}_{2}(\mathrm{kPa})$ & $65 \pm 1.5$ & $6.9 \pm 0.4^{* *}$ & $8.3 \pm 0.8^{* *}$ & $10.7 \pm 2.7^{* *}$ & $14.1 \pm 4.1^{* * \dagger}$ & $32.4 \pm 3.1^{*} \dagger$ & $8.6 \pm 1.3^{* *} \dagger$ \\
\hline $\mathrm{SaO}_{2}(\%)$ & $97 \pm 0.9$ & $73 \pm 6.1^{* *}$ & $82 \pm 5.9^{*} \dagger$ & $79 \pm 7.6^{*}$ & $85 \pm 5.2 * \dagger$ & $97 \pm 0.8 \uparrow$ & $82 \pm 4.9 * \dagger$ \\
\hline $\mathrm{SvO}_{2}(\%)$ & $71 \pm 4.1$ & $42 \pm 2.6^{* *}$ & $41 \pm 3.8 * *$ & $42 \pm 7.4^{* *}$ & $48 \pm 7.5^{*} \dagger$ & $57 \pm 6.3^{*}+$ & $34 \pm 5.6 * * \dagger$ \\
\hline Paw $(\mathrm{kPa})$ & $1.02 \pm 0.07$ & $1.73 \pm 0.13 *$ & $1.71 \pm 0.13^{*}$ & $1.71 \pm 0.14 *$ & $1.72 \pm 0.09 *$ & $1.78 \pm 0.13^{*}$ & $1.78 \pm 0.12^{*}$ \\
\hline Qs/Qt (\%) & $16 \pm 1.1$ & $59 \pm 8.2 * *$ & $43 \pm 6.2 * * \dagger$ & $42 \pm 5.3^{* *}$ & $39 \pm 5.1^{*}$ & $23 \pm 1.6 \dagger$ & $40 \pm 4.6^{* * \dagger}$ \\
\hline
\end{tabular}

$* p<0.05$.

$* * p<0.01$ denotes significant differences to the baseline levels.

$\dagger p<0.05$ denotes a significant difference to the former measured value.

Table 4. Hemodynamic data in six piglets with acute respiratory failure and pulmonary hypertension pre, during and post $P G I_{2}$ application (mean \pm SEM)

\begin{tabular}{|c|c|c|c|c|c|c|c|}
\hline Parameters & Baseline & Lavage + U46619 & $\begin{array}{c}\mathrm{PGI}_{2}-5 \\
(\mathrm{ng} / \mathrm{kg} / \mathrm{min})\end{array}$ & $\begin{array}{c}\mathrm{PGI}_{2}-10 \\
\text { (ng/kg/min) }\end{array}$ & $\begin{array}{c}\mathrm{PGI}_{2}-40 \\
(\mathrm{ng} / \mathrm{kg} / \mathrm{min})\end{array}$ & $\begin{array}{l}\text { PGI }_{2} \text {-Inhal. } \\
\text { (ng/kg/min) }\end{array}$ & Post-PGI 2 \\
\hline Heart rate/min & $161 \pm 8$ & $163 \pm 12$ & $167 \pm 12$ & $185 \pm 10^{* \dagger}$ & $192 \pm 5^{*}$ & $168 \pm 6 \dagger$ & $200 \pm 5^{* * \dagger}$ \\
\hline Cardiac output (L/min) & $2.4 \pm 0.2$ & $1.5 \pm 0.2^{* *}$ & $1.4 \pm 0.2 * *$ & $1.4 \pm 0.2^{* *}$ & $1.33 \pm 0.2 * *$ & $1.3 \pm 0.2 * *$ & $0.70 \pm 0.1^{* * \dagger}$ \\
\hline MAP (kPa) & $9.7 \pm 0.52$ & $11.5 \pm 0.39 *$ & $11.3 \pm 0.93^{*}$ & $11.4 \pm 0.79^{*}$ & $9.8 \pm 0.66 \dagger$ & $11.8 \pm 0.39 * * \dagger$ & $8.6 \pm 1.2 * * \dagger$ \\
\hline MPAP (kPa) & $2.5 \pm 0.26$ & $5.8 \pm 0.53 * *$ & $5.0 \pm 0.53 * * \dagger$ & $5.0 \pm 0.53 * *$ & $4.5 \pm 0.66^{*}$ & $3.72 \pm 0.53 \dagger$ & $5.9 \pm 0.39 * * \dagger$ \\
\hline $\operatorname{PVR}(\mathrm{kPa} / \mathrm{L} / \mathrm{min})$ & $1.1 \pm 0.29$ & $4.34 \pm 0.67 * *$ & $4.0 \pm 0.74 * *$ & $3.9 \pm 0.67 * *$ & $4.2 \pm 0.78 * *$ & $3.4 \pm 0.41 * *$ & $8.4 \pm 0.94 * *+$ \\
\hline $\operatorname{SVR}(\mathrm{kPa} / \mathrm{L} / \mathrm{min})$ & $4.1 \pm 0.35$ & $8.3 \pm 0.86 * *$ & $8.7 \pm 0.94 * *$ & $8.6 \pm 0.86 * *$ & $8.5 \pm 0.86 * *$ & $9.9 \pm 0.95 *+\dagger$ & $11.5 \pm 1.05^{* *} \dagger$ \\
\hline PVR/SVR & $0.25 \pm 0.03$ & $0.51 \pm 0.06^{* *}$ & $0.45 \pm 0.05 * *$ & $0.45 \pm 0.05^{* *}$ & $0.47 \pm 0.06^{* *}$ & $0.32 \pm 0.05^{*} \dagger$ & $0.75 \pm 0.1 * * \dagger$ \\
\hline
\end{tabular}

$* p<0.05$.

${ }^{* *} p<0.01$ denotes significant differences to the baseline levels.

$\dagger p<0.05$ denotes a significant difference to the former measured value.

Although the highest $\mathrm{PaO}_{2} / \mathrm{FiO}_{2}$ values were obtained with inhaled NO of 10-20 ppm, there was no significant difference in oxygenation parameters (Figs. 1 and 2) and pulmonary hemodynamics (Figs. 3 and 4) between NO inhalation and $\mathrm{PGI}_{2}$ aerosol application. However, there was a significant difference in these parameters between NO inhalation and i.v. $\mathrm{PGI}_{2}$ application. After termination of both treatments, oxygenation and hemodynamic deteriorated within $2-5 \mathrm{~min}$ in all animals.

\section{DISCUSSION}

Acute respiratory failure in neonates, infants, and adults is often associated with pulmonary hypertension. In an early stage of acute lung injury, pulmonary hypertension is mediated by vasoactive substances (28), whereas in the late phase structural remodeling of the pulmonary vasculature with medial hypertrophy and reduction in luminal diameter may cause pulmonary hypertension (29). Clinical studies have shown

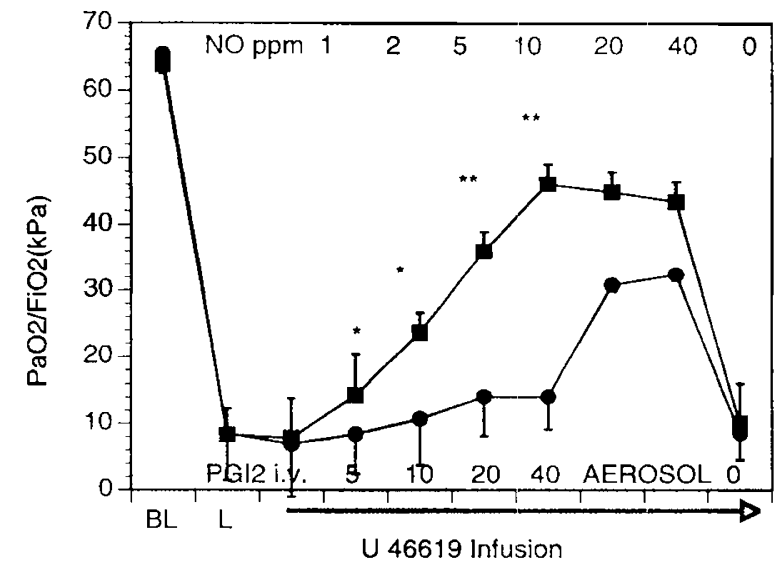

Figure 1. $\mathrm{PaO}_{2} / \mathrm{Fio}_{2}$ ratio (mean $\pm \mathrm{SEM}$ ) during inhaled $\mathrm{NO}$ or inhaled and intravenous $\mathrm{PGI}_{2}$ in acute respiratory failure with pulmonary hypertension. $B L$, baseline. Asterisks indicate differences between both groups (NO, $\mathbf{\square}$, vs $\mathrm{PGI}_{2}$, $0) ;{ }^{*} p<0.05 ;{ }^{*} p<0.01$. 


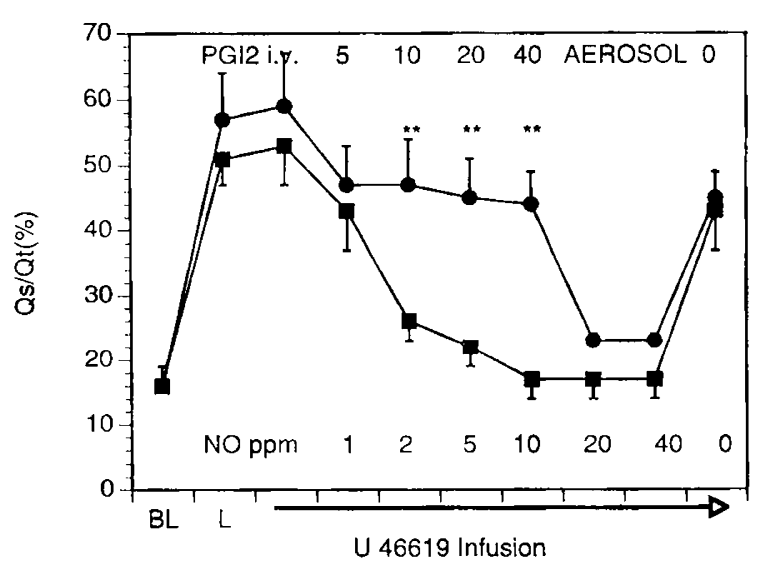

Figure 2. QsQt (mean $\pm \mathrm{SEM}$ ) during inhaled NO or inhaled and intravenous $\mathrm{PGI}_{2}$ in acute respiratory failure with pulmonary hypertension. $B L$, baseline. Asterisks indicate differences between both groups (NO, $\left.\mathbf{\square}, v s \mathrm{PGI}_{2}, \mathbf{0}\right) ;{ }^{* *} p$ $<0.01$.

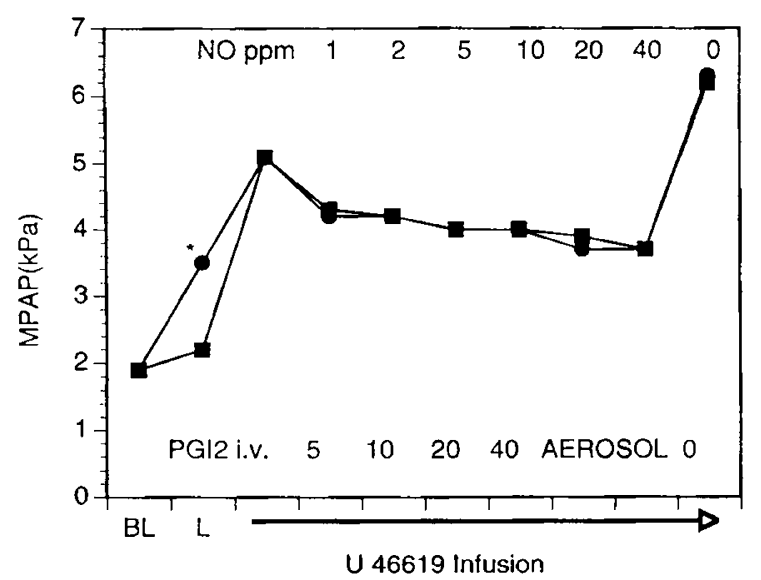

Figure 3. MPAP (mean \pm SEM) during inhaled NO or inhaled and intravenous $\mathrm{PGI}_{2}$ in acute respiratory failure with pulmonary hypetension. $B L$, baseline. Asterisks indicate differences between both groups (NO, $\mathbf{\square}$, vs $\mathrm{PGI}_{2}$, ); $* p<0.05$.

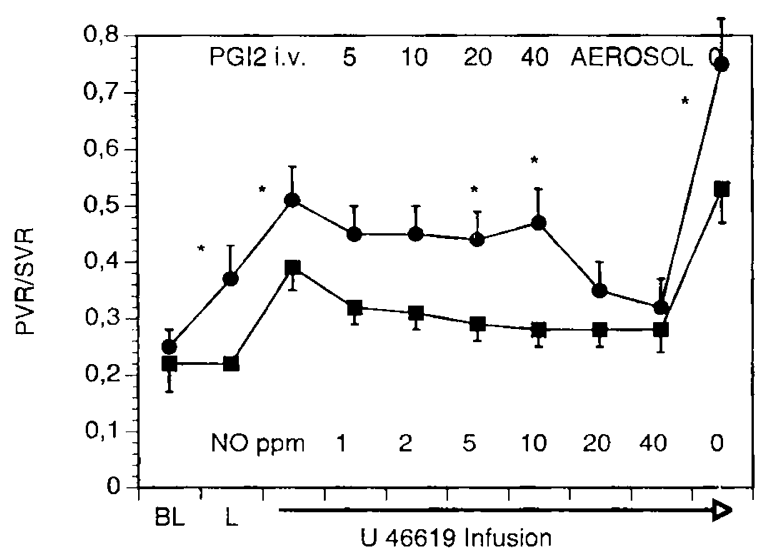

Figure 4. The ratio of PVR to SVR (mean \pm SEM) during inhaled NO or inhaled and intravenous $\mathrm{PGI}_{2}$ in acute respiratory failure with pulmonary hypertension. $B L$, baseline. Asterisks indicate differences between both groups (NO, $\mathbf{\square}$, vs $\mathrm{PGI}_{2}, \mathbf{O}$ ); ${ }^{*} p<0.05$.

increased levels of prostanoids in bronchoalveolar lavage of patients with ARDS (30). In addition, increased levels of circulatory thromboxane $\mathrm{A}_{2}$, a potent vasoconstrictor, may be responsible for pulmonary hypertension in ARDS (31). In our animal model severe acute respiratory failure with pulmonary hypertension was simulated by repeated lung lavages and continuous infusion of U46619.

The main finding of our study was that both inhaled $\mathrm{PGI}_{2}$ and inhaled NO act as selective pulmonary vasodilators with improvement in oxygenation and pulmonary hemodynamics without causing systemic vasodilation.

$\mathrm{PGI}_{2}$ is the main metabolite of arachidonic acid produced in endothelial cells with potent vasodilating properties of both the arterial and venous vasculature. It has been successfully used in a variety of experimental conditions and patients with pulmonary hypertension (21-25). The dosis of i.v. $\mathrm{PGI}_{2}$ application ranges from $5-35 \mathrm{ng} / \mathrm{kg} / \mathrm{min}$. The limitations of i.v. applied $\mathrm{PGI}_{2}$ as a nonselective vasodilator are its risk to systemic hypotension and its possible risk to increased intrapulmonary shunting by vasodilating pulmonary vessels of ventilated and nonventilated areas. Recently, $\mathrm{PGI}_{2}$ was applied as aerosol in three patients with ARDS (26). The authors observed a decrease of PVR by $30 \%$ and a significant increase of $\mathrm{PaO}_{2} / \mathrm{FiO}_{2}$ from $15.9 \pm 2.4 \mathrm{kPa}$ to $22.8 \pm 1.6 \mathrm{kPa}$. The authors concluded that redistribution of blood flow from nonventilated to aerosol-accessible areas resulted in improved matching of ventilation and perfusion and improved oxygenation. In addition, they speculated that an increase in the dose of aerosolized $\mathrm{PGI}_{2}$ might cause "spillover" of the prostanoid into the systemic circulation.

In 1993 Welte et al. (27) reported their investigation on the effects of $\mathrm{PGI}_{2}$ aerosol on pulmonary and systemic circulation compared with NO inhalation in 6 dogs with hypoxic pulmonary hypertension. $\mathrm{A} \mathrm{PGI}_{2}$ aerosol delivered at a rate of $0.87 \pm$ $0.26 \mathrm{ng} / \mathrm{kg} / \mathrm{min}$ reduced hypoxia-induced increase of PAP by $48 \%$ and PVR by $52 \%$ within $6-10$ min without systemic vasodilation. NO inhalation of $50 \mathrm{ppm}$ decreased PAP and PVR by $76 \%$ and $73 \%$, respectively. The authors concluded that aerosolized $\mathrm{PGI}_{2}$ is a selective pulmonary vasodilator, but less potent than inhaled NO, in hypoxia induced pulmonary hypertension. In our study inhaled $\mathrm{PGI}_{2}$ significantly improved oxygenation, reduced Qs/Qt, PAP, and PVR with no influence on the systemic vasculature. Intravenous $\mathrm{PGI}_{2}$ slowly improved oxygenation. In contrast to other findings doses up to $40 \mathrm{ng} / \mathrm{kg} / \mathrm{min}$ did not increase Qs/Qt. Whereas PAP decreased significantly during i.v. $\mathrm{PGI}_{2}$ infusion $\mathrm{MAP}$ remained stable up to a $\mathrm{PGI}_{2}$ infusion rate of $10 \mathrm{ng} / \mathrm{kg} / \mathrm{min}$. However, a significant decrease in MAP was noticed during infusion of $40 \mathrm{ng} / \mathrm{kg} / \mathrm{min}$ of $\mathrm{PGI}_{2}$. The PVR/SVR ratio was significantly lower during inhaled $\mathrm{PGI}_{2}$ than during i.v. $\mathrm{PGI}_{2}$ indicating the local vasodilating effect of inhaled $\mathrm{PGI}_{2}$. In our study the inhaled $\mathrm{PGI}_{2}$ dose of $30-60 \mathrm{ng} / \mathrm{kg} / \mathrm{min}$ was significantly higher than the dose applied by Welte et al. (27) in dogs and slightly higher than the dose applied to humans with ARDS (26). The real aerosol deposit in the lungs is rather small $(<5 \%)(31,32)$ and cannot be easily determined. In our animal trial we did not measure $\mathrm{PGI}_{2}$ aerosol particles in the airways and did not measure $\mathrm{PGI}_{2}$ metabolites in the circulation. However, from the clinical point of view the inhaled $\mathrm{PGI}_{2}$ aerosol was effective in terms of improved oxygenation and pulmonary circulation without negative systemic vascular effects. However, the exact dose and the optimal form of $\mathrm{PGI}_{2}$ aerosol delivery has to be 
shown in further studies. Inhaled $\mathrm{PGI}_{2}$ was reported to have bronchodilatory effects in asthma (33). However, our results did not show any effect on Raw either during $\mathrm{PGI}_{2}$ infusion or aerosol therapy.

Inhaled NO has been demonstrated to be beneficial in adults with pulmonary hypertension (19) and ARDS (18), infants and children with ARDS (17) and pulmonary hypertension associated with congenital heart disease (33), and neonates with pulmonary hypertension (13). Inhaled NO has been shown to reverse acute pulmonary vasoconstriction induced by hypoxia, by a thromboxane analog, or by the heparin-protamin reaction $(7,8)$. The vasodilator effect of inhaled NO occurred selectively in the pulmonary vessels without causing systemic vasodilation. Recently, Etches et al. (12) reported that NO reverses acute hypoxic pulmonary hypertension in the newborn piglet. The animals were given varying concentrations of inhaled NO between 5 and 80 ppm. All doses of NO significantly reduced PAP and PVR with no significant differences between the various doses of NO (12). In our present study a significant increase in oxygenation and a significant decrease in PAP occurred at an inhaled NO concentration of $1 \mathrm{ppm}$. Furthermore, oxygenation improved constantly with increasing NO concentrations up to $10 \mathrm{ppm}$. However, further increases in inhaled NO concentration resulted in a slight decrease in oxygenation. This might be due to a lower $\mathrm{FiO}_{2}\left(\mathrm{FiO}_{2} 0.9\right.$ at 40 ppm NO versus $1.0-0.98$ at $1-10$ ppm NO). The lowest PAP levels were seen during $40 \mathrm{ppm}$ of NO. Although PAP decreased significantly in our study, there was no change in PVR. The continuous infusion of U46619 constantly increased systemic vasoconstriction resulting in a gradual decline in cardiac output. The PVR/SVR ratio decreased significantly during NO inhalation, indicating the local vasorelaxing effect of inhaled NO. Recently, Gerlach et al. (35) observed improved oxygenation in adults with ARDS with unchanged PAP at very low concentrations of inhaled NO $(<1 \mathrm{ppm})$. They concluded that improved oxygenation results from redistribution of blood flow from nonventilated to ventilated areas of the lungs and not from enhanced pulmonary perfusion.

In our study the $\mathrm{PaO}_{2} / \mathrm{FiO}_{2}$ ratio was higher and Qs/Qt was lower during inhaled $\mathrm{NO}$ of $10 \mathrm{ppm}$ than during inhaled $\mathrm{PGI}_{2}$. Both inhalational therapies decreased significantly the PAP without any influence on MAP. These findings indicate that both inhaled substances decrease PAP sufficiently and that inhaled NO better improves ventilation-perfusion imbalance than inhaled $\mathrm{PGI}_{2}$. Dupuy et al. (36) demonstrated in guinea pigs that inhaled NO reduced the increased pulmonary resistance induced by an i.v. methacholine infusion by $50 \%$. In contrast Zayek et al. (11) could not find any effect of inhaled NO on Raw and tidal volume in newborn lambs with pulmonary hypertension. Our results confirm this finding.

$\mathrm{NO}$ is rapidly converted to $\mathrm{NO}_{2}$ and other toxic oxides of nitrogen by oxidation that can be toxic to the lungs. Greenbaum et al. (6) published that inhalation of $2 \% \mathrm{NO}$ or $\mathrm{NO}_{2}$ resulted in death due to methemoglobinemia, hypoxemia, and pulmonary edema. The conversion of $\mathrm{NO}$ to $\mathrm{NO}_{2}$ depends on the $\mathrm{NO}$ concentration, the $\mathrm{FiO}_{2}$, and the contact time of both gases. As in our trial, NO was inhaled into the inspiratory limb of the ventilatory circuit near the endotracheal tube and the inspired concentrations of $\mathrm{NO}_{2}$ were measured to be less than $0.5 \mathrm{ppm}$ even at NO concentrations of $40 \mathrm{ppm}$. NO is rapidly bound to $\mathrm{Hb}$ in the vascular system producing methemoglobin. NO concentrations up to $80 \mathrm{ppm}$ did not increase methemoglobin concentrations in animal trials ( 7 ). We measured methemoglobin concentrations up to $2 \%$ during $\mathrm{NO}$ inhalation of $40 \mathrm{ppm}$. However, critical levels of methemoglobinemia with reduced oxygen transport might follow prolonged inhalation of high doses of NO. Because of the possible toxicities, as methemoglobinemia due to $\mathrm{NO}$ and direct pulmonary injury due to $\mathrm{NO}_{2}$, NO should be applied cautiously with continuous monitoring of inspiratory $\mathrm{NO}$ and $\mathrm{NO}_{2}$ concentrations.

In conclusion, both inhaled $\mathrm{NO}$ and $\mathrm{PGI}_{2}$ act as a selective pulmonary vasodilators in acute respiratory failure with pulmonary hypertension resulting in improved oxygenation mainly due to improved mismatch of pulmonary perfusion and ventilation. Both inhaled substances have no effects on Raw and Cst. The application of inhaled NO is rather simple. Because of its possible toxicity, inhaled NO requires measurement of $\mathrm{NO}$ and $\mathrm{NO}_{2}$ on a continuous basis. As aerosolized $\mathrm{PGI}_{2}$ has no known toxic side effects, measurement of the inspired concentration is not necessary. However, the exact dose and aerosol application form has to be investigated in further studies. Intravenous $\mathrm{PGI}_{2}$ improves oxygenation and pulmonary hemodynamics to a less extent than aerosolized $\mathrm{PGI}_{2}$ and has the risk of systemic hypotension at a higher dose.

Acknowledgments. The authors thank Elisabeth Horvat, Ursula Schreiner, and Franziska Sommer for their help. The authors also thank Prof. Dr. Steindorfer (Head of the Department of Experimental Surgery, University of Graz, Austria) for technical support.

\section{REFERENCES}

1. Ignarro LJ, Buga GM, Wood KS, Byrns RE, Chauhuri G 1987 Endothelium-derived relaxing factor produced and released from artery and vein is nitric oxide. Proc Natl Acad Sci USA 84:9265-9269

2. Palmer RMJ, Ferrige AG, Moncada SA 1987 Nitric oxide release accounts for the biological activity of endothelium-derived relaxing factor. Nature 327:524-526

3. Ignarro LJ 1989 Biological actions and properties of endothelium-derived nitric oxide formed and released from artery and vein. Circ Res 65:1-21

4. Meyer M, Piiper J 1989 Nitric oxide (NO), a new test gas for study of alveolarcapillary diffusion. Eur Resp J 2:494-496

5. Beckman JS, Beckman TW, Chen J, Marshall PA, Freeman BA 1990 Apparent hydroxyl radical production by peroxynitrite: Implications for endothelial injury from nitric oxide and superoxide. Proc Natl Acad Sci USA 87:1620-1624

6. Greenbaum R, Bay J, Hargreaves MD, Kain ML, Kelman GR, Numm JF, PrysRoberts C, Siebold K 1967 Effects of higher oxides of nitrogen on the anaesthetized dog. Br J Anaest 39:393-404

7. Frostell C, Fratacci MD, Wain JC, Jones R, Zapol WM 1991 Inhaled Nitric Oxide: A selective pulmonary vasodilator reversing hypoxic pulmonary vasoconstriction. Circulation 83:2038-2047

8. Fratacci C, Fratacci MD, Wain J, Jones R, Zapol WM 1991 Inhaled nitric oxide: a selctive pulmonary vasodilator of heparin-protamine vasoconstriction in sheep. Anesthesiology 75:990-999

9. Roberts JD, Chen TY, Kawai N, Wain J, Dupuy P, Shimouchi A, Bloch K, Polaner D, Zapol WM 1993 Inhaled nitric oxide reverses pulmonary vasoconstriction in the hypoxic and acidotic newborn lamb. Circ Res 72:246-254

10. Kinsella JP, McQueston JA, Rosenberg AA, Abman SH 1992 Hemodynamic effects of exogenous nitric oxide in ovine transitional pulmonary circulation. Am J Physiol 263:H875-H880

11. Zayek M, Cleveland D, Morin III FC 1993 Treatment of persistent pulmonary hypertension in the newborn lamb by inhaled nitric oxide. J Pediatr 122:743-750

12. Etches PC, Finer NN, Barrington KJ, Graham AJ, Chan WKY 1993 Nitric oxide reverses acute hypoxic pulmonary hypertension in the newborn piglet Pediatr Res $35: 15-19$

13. Roberts JD, Polaner DM, Lang P, Zapol WM 1992 Inhaled nitric oxide in persistent pulmonary hypertension of the newborn. Lancet 340:818-819 
14. Kinsella JP, Neish SR, Shaffer E, Abman SM 1992 Low-dose inhalational nitric oxide in persistent pulmonary hypertension of the newborn. Lancet 340:819-820

15. Kinsella JP, Toews WH, Henry D, Abman SH 1993 Selective and sustained pulmonary vasodilation with inhalational nitric oxide therapy in a child with idiopathic pulmonary hypertension. J Pediatr 122:803-806

16. Finer NN, Etches PC, Kamstra B, Tierney AJ, Peliowski A, Ryan AC 1994 Inhaled nitric oxide in infants referred for extracorporeal membrane oxygenation: Dose response. J Pcdiatr 124:302-308

17. Abman SH, Griebel JF, Parker DK, Schmidt JM, Swanton D, Kinsella JP 1994 Acute effects of inhaled nitric oxide in children with severe hypoxemic respiratory failure. J Pediatr 124:881-888

18. Rossaint R, Falke KJ, Lopez F, Salma K, Pison U, Zapol WR 1993 Inhaled nitric oxide for the adult respiratory distress syndrome. N Engl J Med 328:399-405

19. Pcpke-Zaba J, Higenbottam TW, Dinh-Xuan AT, Stone D, Wallwork J 1991 Inhaled nitric oxide as a cause of selective pulmonary vasodilation in pulmonary hypertension. Lancet 338:1173-1174

20. Kadowitz PJ, Chapnik BM, Feigen LP, Hyman AL, Nelson PK, Spannhake EW 1978 Pulmonary and vasodilator effects of the newly discovered prostaglandin, $\mathrm{PGI}_{2} . \mathrm{J}$ Appl Physiol 45:408-413

21. Devitt HH, Burka JF, Jone R, Amy RW, King EG 1988 Hemodynamic and pathologic effects of prostacyclin on oleic acid-induced pulmonary injury. Surgery 103:213-220

22. Owall A, Davilen J, Sollevi A 1991 Influence of adenosine and prostacyclin on hypoxia-induced pulmonary hypertension in the anaesthetized pig. Acta Anaesthesiol Scand 35:350-354

23. Radermacher P, Santak B, Wust HJ, Tarnow J, Falke KJ 1990 Prostacyclin for the treatment of pulmonary hypertension in the adult respiratory distress syndrome: Effects on pulmonary capillary pressure and ventilation-perfusion distributions. Anesthesiology 72:238-244

24. Higenbottam $\mathrm{T} 1987$ The place of prostacyclin in the clinical management of primary pulmonary hypertension. Am Rev Respir Dis 136:782-785
25. Bihari D, Smithies M, Gimson A, Tinker J 1987 The effects of vasodilation with prostacyclin on oxygen delivery and uptake in critically ill patients. N Engl J Med 317:397-403

26. Walmrath D, Schneider T, Pilch J, Grimminger F, Seeger W 1993 Aerosolised prostacyclin in adult respiratory distress syndrome. Lancet 342:961-962

27. Welte M, Zwissler B, Habazettl $\mathrm{H}$, Messmer $\mathrm{K} 1993 \mathrm{PGI}_{2}$ aerosol versus nitric oxide for selective pulmonary vasodilation in hypoxic pulmonary vasoconstriction. Eur Surg Res 25:329-340

28. Winn R, Harlan J, Nadir B, Harker L, Hildebrandt J 1983 Thromboxane A mediates lung vasoconstriction but not permeability after endotoxin. J Clin Invest 72:911-918

29. Tomashefski JF, Davies P, Boggis C, Zapol WM, Reid LM 1983 The pulmonary vascular lesions of the adult respiratory distress syndrome. Am J Pathol 112:112-126

30. Leeman M, Boeynaems JM, Degaute JP, Vincent JL, Kahn RJ 1985 Administration of dazoxiben, a selective thromboxane synthetase inhibitor, in the adult respiratory distress syndrome. Chest 87:726-730

31. Fuller HD, Dolovich MB, Posmituck G, Wong Pack W, Newhouse MT 1989 Pressurized aerosol versus jet aerosol delivery to mechanically ventilated patients. Am Rev Respir Dis 141:440-444

32. Macintyre N, Silver R, Miller C, Schuler F, Colemean E 1985 Aerosol delivery to intubated patients, mechanically ventilated patients. Crit Care Med 13:81-84

33. Hardy CC, Bradding P, Robinson C, Holgate ST 1988 Bronchoconstrictor and anti-bronchoconstrictor properties of inhaled prostacyclin in asthma. J Appl Physiol 64:1567-1574

34. Roberts JD, Lang P, Bigatello LM, Vlahakes GJ, Zapol WM 1993 Inhaled nitric oxide in congenital heart disease. Circulation 87:447-453

35. Gerlach H, Rossaint R, Pappert D, Falke KJ 1993 Time-course and dose-response of nitric oxide inhalation for systemic oxygenation and pulmonary hypertension in patients with adult respiratory distress syndrome Eur J Clin Invest 23:499-502

36. Dupuy PM, Shore SA, Drazen JM, Frostell C, Hill WA, Zapol WM 1992 Bronchodilator action of inhaled nitric oxide in guinea pigs. J Clin Invest 90:421-428 